\begin{tabular}{c} 
Volume and Issues Obtainable at Center for Sustainability Research and Consultancy \\
Journal of Accounting and Finance in Emerging Economies \\
ISSN: 2519-0318 ISSN (E) 2518-8488 \\
Volume 3: Issue 2 December 2017 \\
JSRᄃ \\
Journal homepage: www.publishing.globalcsrc.org/jafee \\
\hline
\end{tabular}

\title{
Develop and Engage Talents: A Preliminary Study at Islamic Banks in Northern Region of Malaysia
}

\author{
${ }^{1}$ Bidayatul Akmal Mustafa Kamil, ${ }^{2}$ Fatin Izzati Iqbal \\ ${ }^{1}$ Lecturer, School of Business Management, Universiti Utara Malaysia, Malaysia. \\ bidayatul@uum.edu.my \\ ${ }^{2}$ Research Scholar, School of Business Management, Universiti Utara Malaysia, Malaysia. \\ izzatiiqbal@gmail.com
}

\begin{tabular}{|c|c|}
\hline ARTICLEDETAILS & ABSTRACT \\
\hline History & Purpose: Attract, select, develop and engage the right talents at the right \\
\hline Revised format: Nov 2017 & time, place and position become essential for upgrading the management \\
\hline Available online: Dec 2017 & system in the banking sector. This study identifies the development of \\
\hline Keywords & $\begin{array}{l}\text { talents through talent management and succession planning, which may } \\
\text { engage those employees with the banks. }\end{array}$ \\
\hline Talent Development, & Design/Methodology/Approach: In this preliminary study, 180 copies of \\
\hline Talent Management, & questionnaires were distributed to the bankers who are currently working \\
\hline Succession Planning, & with some Islamic Banks in the Northern region of Malaysia; Kedah, Perlis \\
\hline Engagement, & and Pulau Pinang. The simple random sampling techniques applied. The \\
\hline Islamic Banks & analysis of this study are all descriptive. \\
\hline & Findings: This study explores the descriptive analysis on talent \\
\hline $\begin{array}{l}\text { JEL Classification: } \\
Q 0, G 21, Z 21\end{array}$ & $\begin{array}{l}\text { management, succession planning and talent engagement, that might be } \\
\text { particularly focus on the mean of each variables. The analyses show that, } \\
\text { the respondents believed that talent management and succession planning, } \\
\text { as well as talent engagement should well-known exist and outstandingly } \\
\text { being implemented in Islamic banking industry. }\end{array}$ \\
\hline & $\begin{array}{l}\text { Implications/Originality/Value:Islamic banks demand for talents of } \\
\text { bankers that are not only well profound with Sharia knowledge but also } \\
\text { capable to ascertain the differences between Islamic banking and finance } \\
\text { regulation at par with conventional practices. The analyses of the data are } \\
\text { expected to give practical contribution to the Islamic banks to have a better } \\
\text { talent management mechanism and succession planning program for } \\
\text { engaging their talents in the future. }\end{array}$ \\
\hline
\end{tabular}

(C) 2017 The authors, under a Creative Commons Attribution-

NonCommercial 4.0

Corresponding author's email address: bidayatul@uum.edu.my

Recommended citation:Kamil,B.A.M.\&Iqbal.F.I., (2017). Develop and Engage the Islamic Banks' Talents: A Preliminary Analysis. Journal of Accounting and Finance in Emerging Economies, 3(2) 113-124.

DOI:https://doi.org/10.26710/jafee.v3i2.91

\section{Introduction}

The Islamic banking system has exposed a remarkable growth over the last 30 years when it has been existent from a time in year 1970. Throughout 2004, the resources of Islamic banking industry had grasped hundred billions of dollars, including most countries from East to the West of the globe, by 
highlighting Malaysia, Bahrain, Europe and United States. At present, the Islamic banking practices have spread all over the world. In fact, most of the banks are now actively involved in the Islamic banking system. At the moment, Malaysia is successfully implementing a dual banking system and at the same time has developed as a first nation that has good full-fledged Islamic banking systems. These systems operate based on the parallel basis which aligns with the conventional banking system.In Malaysia, Bank Islam Malaysia Berhad (BIMB) was the first Islamic bank and was operated as the only Islamic bank for the past 10 years before the Malaysian government gives permission to other conventional banks to offer Islamic banking services to the customers. The government decided to allow the conventional banks to use the existing infrastructure and branches to operate in the Islamic banking sector which is known as the 'Islamic windows'. This is to provide cost effective and shortest time frame, as well as to increase the number of institutions that offer the Islamic banking services. Through this action, it leads the Malaysian banking industry to be more competitive which directly improves the performance and efficiency of the banking industry (Alias et al., 1994; Kaleem, 2000).

According to MohdPisal (2012), bankers in any banks that are upright prepared with the FiqhMuamalah and Maqasid Sharia knowledge will be able to discover the differences between the Islamic banking terms and regulation implementation. The Islamic banking institution in Malaysia entails approximately around 20,000 workforces by 2020 (MIFC, 2013). Therefore, talent management practice and succession planning play an important role to create a talent which is good in both areas; Islamic or Sharia knowledge and banking knowledge. Furthermore, there is a need for improvement in the management systems in the banking sector in order to make sure that the talents are engaging well with the bank. Hence, this study will explore the variables of talent management, succession planning and talent engagement based on the perspectives of bankers from the Islamic bank.

\section{Literature Review}

Attracting, selecting, developing and retaining talent is very crucial to increase the potential and performance level among the talents. It is also to increase the individual's success level in performing the task using their own abilities (Garavan, Carberry \& Rock 2012)and to continuously improve their position. A proper initiative for talent development will lead to a better development in the organization. This means that the knowledge, skills and abilities of the talents can be developed through the behavioral modification activity such as technical training and coaching (Birdi, 2005; Brooks and Nafukho, 2006). Furthermore, an effective development and assessment plan should be implemented by the organization in order to make sure that the talents are developing well (Glen, 2007) and suitable for all the task given. To develop the talents, the implementation of talent management and succession planning are needed (Rothwell, 2011).

\subsection{Talent Management}

Talent management is very significant to the organization as it attracts and retains essential talents and at the similar period will lead to talent engagement in the organization (Morton, 2005). The combination of these issues has become one of the main contributing factors of achievement and vibrant concerns for organizations (Hughes \& Rog, 2008). Many organizations around the world have started to reduce the costs and focused more on their abilities by investing in the long term strategies after the global financial crisis that had happened in the year 2008. In fact, they have started to develop good management skills in order to support the integrated talent management strategy that can boost up the successfulness of a business (Rowland, 2011).

\subsection{Succession Planning}

Currently, succession planning has convert a major area for the human resource management. The organization can save some money instead of recruiting new employees and they can provide a training 
session and offer career promotion to the talents (Hill, 2009). Successful succession planning is a series of activities that fulfill the scope and movement of the leadership (Charan, Drotter, Noel, 2001). According to Oxford Advanced Learner's Dictionary (2005), succession planning is defined as a process of training and preparing the talents in the organization so that there will always have a right person to replace the senior manager once they leave. Furthermore, it shows that professional development of the internal talents is the main key in maintaining the smooth transition between the organizations and the talents when the job replacement occurs. As supported by Rollins (2003), succession planning serves to aid the recruitment and retention process among the talents in the organization and making it clear to fill in the senior positions from within.

\subsection{Talent Engagement}

The engaged talents are those people who gave great commitment and effort in performing their work and mostly they are highly vigorous and dedicated talents while the disengaged talents are those who intentionally disconnected from work commitments and do not have the energy or strength to work hard which prevents them to not being able to commit to the work (Bakker et al. 2008; Towers Perrin 2009). The engagement among talents has great impacts toward the productivity, profitability, employee retention and customer services (Zigarmi et al. 2009; Xanthopoulou et al. 2009). In fact, there are a few reasons why the engaged talents perform better than disengaged talents (Bakker \&Demrouti, 2008). First, engaged talents are usually working with positive emotions. Second, engaged talents are enjoying a better health. Third, engaged talents are creative because they can create their own job and personal resources. Fourth, the engaged talents frequently transfer their engagement to other talents by spreading positive vibe in the working place.

\section{Methodology}

The population of this research primarily refers to the Islamic banking sector employees.Constructed on the sample frame by Krejcie and Morgan (1970) from the total population of N=340 of Islamic banks' northern region bankers, a total of 180 respondents were selected to complete the survey. Total respondents that answered and replied upright in this research are 118 peoples. In this research, selfadministered questionnaires were given to selected respondents. The instruments for talent management are adopted from the Dries (2013), succession planning from Rothwell (2010), and engagement from Schaufeli (2003).In this research, descriptive analysis has been utilized to measure talent management, succession planning and talent engagement. The result is shown in mean and the highest mean determines that the respondents are most likely aware of the importance of particular variables towards the talent engagement.

\subsection{Findings and Discussions 4.1 Background of the Respondents}

The selected bankers were mostly equal between the female and male who voluntarily participated in this study. Based on the findings, it was found that 57 are males and 61 are females' respondents. Out of the 118 respondents, 24 persons have less than 5 years' experience working with banks while 6 persons works more than 30 years with banks. This study involved mostly 1:1 proportion between both gender who have experience less than 5 years and more than 30 years. Female than has 5-10 years' experience and 20-30 years' experience have greater number than male. But those male that have 10-20 years' experience have greater number than female. This study should be no bias based on the gender and working experience. 
Table 1.1: Total Respondents Based on Gender and Working Experience

\begin{tabular}{cccccccc}
\hline & & \multicolumn{6}{c}{ Working Experience (years) } \\
& $<5$ & $5-10$ & $10-20$ & $20-30$ & $>30$ & Total \\
\hline \multirow{2}{*}{ Gender } & Male & 12 & 10 & 19 & 13 & 3 & 57 \\
& Female & 12 & 13 & 18 & 15 & 3 & 61 \\
\hline \multicolumn{2}{c}{ Total } & 24 & 23 & 37 & 28 & 6 & 118 \\
\hline
\end{tabular}

Table 1.2:Descriptive response from the respondents

\begin{tabular}{lccc}
\hline & & Frequency & Percent (\%) \\
\hline Definition of Key Talent & Yes & 56 & 47.9 \\
& No & 61 & 52.1 \\
\hline Identified Key Talent & Yes & 90 & 76.9 \\
& No & 27 & 23.1 \\
\hline Major Challenges & Strongly Disagree & 14 & 12 \\
& Disagree & 3 & 2.6 \\
& Neutral & 35 & 29.9 \\
& Agree & 52 & 44.4 \\
& Strongly Agree & 13 & 11.1 \\
\hline
\end{tabular}

Based on the descriptive response from the respondents, 61 respondents $(52.1 \%)$ admit that they have no idea and less knowledge about the formal definition of key talents and only 56 respondents (47.9\%) have the idea and knowledge about a key talent in their organization. However, $90(76.9 \%)$ of the respondents agreed that their organization had identified a key talent, while the remaining $27(23.1 \%)$ of the respondents stated that their organization has not managed to identify a key talent.

Among the 117 respondents, only 52 respondents (44.4\%) agreed that identifying a key talent is a major challenge in the organization which they are working with. Meanwhile, 35 respondents (29.9\%) classified it as neutral and 13 respondents (11.1\%) classified it as strongly agree. However, 14 (12.0\%) and 3 $(2.6 \%)$ of the respondents strongly disagree and disagree with the statement that "identify a key talent is a major challenge in their organization".

\subsection{Reliability Analysis}

The result shows that all the independent variables were ranged as very good because the value is more than 0.8. Therefore, it can be concluded that that the questions of independent variables are reliable to be used for this research study.

Table 1.3: The result of Reliability Test

\begin{tabular}{ccc}
\hline Variables & No. of Items & Cronbach's Alpha \\
\hline Talent Management & 24 & 0.95 \\
Succession Planning & 13 & 0.93 \\
Talent Engagement & 17 & 0.94 \\
\hline
\end{tabular}

\subsection{Mean Score}

Interpretation of mean scores as shown in Table 1.4 is to determine the level of each variables. The researcher divided mean scores for the talent management, succession planning and employee engagement into four levels, namely low, medium low, medium high and high. The results show that all the mean of the variables are interpreted as medium high. 
Table 1.4:Mean Score Interpretation

\begin{tabular}{cc}
\hline Mean Score & Mean Score Interpretation \\
\hline $1.00-2.00$ & Low \\
\hline $2.01-3.00$ & Medium Low \\
\hline $3.01-4.00$ & Medium High \\
\hline $4.01-5.00$ & High \\
\hline Source: Norasmah Othman 2002; pp. 202.
\end{tabular}

\subsubsection{Talent Management}

Based on the Table 1.5, most of the respondents have a high concern and a good knowledge of talent management that had been practicing in their bank. The mean for talent management is 3.66 (Std. Dev. = 0.436). They believe that talent management is a very important aspect that will lead to talent engagement among the bankers. Furthermore, they stressed that the talent management is necessary in order to select the best candidates to take over the managerial position when there is an available vacancy. Based on the result, attracting (3.67), selecting (3.65), developing (3.63) and retaining (3.71) plays a vital role to support the talent management.

In attracting talent, the respondents highly claimed that their organization sees talent management as vital to banking success. When selecting talents, all of the respondents agreed that their organization uses objective criteria to select talented candidates, carries out orientation programs to adapt new candidates with the bank's rules and introduces enough promotions for talented employees. While to develop talents, the respondents indicated that the organization need to determine training needs accurately. Moreover, they realized that to retain talents, the organization must care with career development for existing employees. These factors are the mean which at the highest rank (number one that prioritize among the list). The results indicate that the success of a bank relies on talent management based on some important criteria such as training and development program, as well as their career development.

Table 1.5:Talent Management

\begin{tabular}{|c|c|c|}
\hline Questions & Mean & $\begin{array}{l}\text { Standard } \\
\text { Deviation }\end{array}$ \\
\hline TALENT MANAGEMENT & 3.66 & 0.436 \\
\hline ATTRACTING TALENT & 3.67 & \\
\hline 1. My organization attracts talent effectively & 3.61 & 0.615 \\
\hline $\begin{array}{l}\text { 2. My organization has processes in place to align talent management to } \\
\text { bank goals }\end{array}$ & 3.64 & 0.579 \\
\hline 3. My organization has a succession plan in place & 3.67 & 0.657 \\
\hline $\begin{array}{l}\text { 4. My organization has processed and policies to support talent } \\
\text { management }\end{array}$ & 3.75 & 0.615 \\
\hline 5. My organization sees talent management as vital to banking success & 3.76 & 0.678 \\
\hline 6. My organization considers talent management one of its reference values & 3.59 & 0.709 \\
\hline SELECTING TALENT & 3.65 & \\
\hline 1. My organization uses objective criteria to select talented candidates & 3.68 & 0.717 \\
\hline 2. My organization depends on depth interviews to select skilled candidates & 3.55 & 0.636 \\
\hline $\begin{array}{l}\text { 3. My organization carries out orientation programs to adapt new candidates } \\
\text { with the bank's rules }\end{array}$ & 3.68 & 0.654 \\
\hline 4. My organization introduces enough promotions for talented employees & 3.68 & 0.652 \\
\hline 5. My organization shows clear replacement charts for talented employees & 3.63 & 0.638 \\
\hline $\begin{array}{l}\text { 6. My organization frequently communicates the importance of talent } \\
\text { management }\end{array}$ & 3.67 & 0.557 \\
\hline
\end{tabular}




\section{DEVELOPING TALENT}

1. My organization determines training needs accurately

3.63

3.75

0.655

2. My organization appraises performance of existing employees accurately to discover their strengths and weakness

3. My organization keeps with talented employees through suitable workplace conditions

3.68

0.665

3.54

0.664

4. My organization established human resource planning to ensure skills utilization

0.601

5. My organization has capabilities to develop talent strategies aligned with banks' strategies

6. My organization introduces enough opportunities to develop talented employees

\section{RETAINING TALENT}

1. My organization supports effective talent management through workplace layout and physical plant

$3.63 \quad 0.624$

\subsection{1}

3.74

0.589

2. My organization designs a motivational plan for wages and benefits

3.69

0.622

3. My organization retains the talent needed to achieve bank goals

3.71

0.573

4. My organization has enough budget to support talent management

3.63

0.664

5. My organization has technological capabilities needed to facilitate talent management

3.71

0.603

6. My organization cares with career development for existing employees
0.721

\subsubsection{Succession Planning}

Based on Table 1.6, most of the respondents believe that succession planning plays an important role towards the talent engagement among the bankers. The mean for succession planning is 3.76 (Std. Dev. = 0.462). They believe that the need of succession planning able to strengthen their level of engagement towards the bank. Therefore, proper succession planning programs need to be done in order to achieve a positive outcome on the talent engagement.

Most of the bankers agreed that succession planning can increase the talent pool of the promotable employees. However, the respondents were less highlights about the succession planning than can cope with the effects of the voluntary separation programs, such as early retirement offers and employee buyouts. Even though it is not a main priority among other factors in the survey items, the mean 3.61 with standard deviation of 0.601 still fall down under "agree" to justify those respondents decision.

Table 1.6: Succession Planning

\begin{tabular}{lcc}
\multicolumn{1}{c}{ Questions } & Mean & $\begin{array}{c}\text { Standard } \\
\text { Deviation }\end{array}$ \\
\hline SUCCESSION PLANNING & $\mathbf{3 . 7 6}$ & $\mathbf{0 . 4 6 2}$ \\
1. Succession planning has contributed to implementing the & 3.84 & 0.656 \\
$\quad \begin{array}{l}\text { organization's Strategic Business Plans } \\
\text { 2. Succession planning can cope with the effects of downsizing or } \\
\text { other staff reductions }\end{array}$ & 3.66 & 0.590 \\
3. Succession planning can cope with the effects of the voluntary & & \\
$\quad \begin{array}{l}\text { separation programs, such as early retirement offers and } \\
\text { employee buyouts }\end{array}$ & 3.61 & 0.601 \\
4. Succession planning can help individuals realize their career & 3.74 & 0.649 \\
$\quad \begin{array}{l}\text { plans within the organization } \\
\text { 5. Succession planning can improve employee morale }\end{array}$ & 3.68 & 0.599
\end{tabular}


6. Succession planning can improve employees' ability to respond to changing environmental demands

$3.71 \quad 0.573$

7. Succession planning can reduce headcount to essential workers only

$3.76 \quad 0.625$

8. Succession planning can increase the talent pool of the promotable employees

$3.85 \quad 0.624$

9. Succession planning can identify "replacement needs" as a means of targeting necessary training, employee education and employee development

10. Succession planning can decide what workers can be terminated without damage to the organization

$3.79 \quad 0.680$

11. Succession planning can encourage the advancement of diverse groups, such as minorities or women in the future jobs within the organization

12. Succession planning provides increased opportunities for "high potential", workers

$3.81 \quad 0.656$

$3.83 \quad 0.660$

13. Succession planning can untapped the potential for intellectual capital in the organization

\section{$3.83 \quad 0.647$}

\subsubsection{Talent Engagement}

The Table 1.7 shows the mean score of the dependent variable in the study. The mean for talent engagement is 3.68 (Std. Dev. = 0.506). This is an indication that most of the respondents have agreed with the talent engagement. Furthermore, they will make a good effort to maintain their level of engagement towards the banks, which they are currently working with. For an example, 55.6\% of the respondents agreed with the statement 'I feel strong and vigorous at work', while $39.3 \%$ answered it as neutral.

Talent engagement that divided into three categories that are vigor, dedication and absorption explains that the respondents engage with their employers when highlights that they always continue working even when things do not go well, they are enthusiastic about their current job and feel that time flies when they are working.

Table 1.7: Frequency Analysis of Talent Engagement for each question

\begin{tabular}{lrc}
\multicolumn{1}{c}{ Questions } & Mean & $\begin{array}{c}\text { Standard } \\
\text { Deviation }\end{array}$ \\
\hline TALENT ENGAGEMENT & $\mathbf{3 . 6 8}$ & $\mathbf{0 . 5 0 6}$ \\
\hline VIGOR & $\mathbf{3 . 5 7}$ & \\
\hline 1. I feel bursting with energy at work & 3.59 & 0.559 \\
2. I feel strong and vigorous at work & 3.60 & 0.644 \\
3. Every day I feel like going to work & 3.51 & 0.624 \\
4. I can continue working for very long periods at a time & 3.55 & 0.676 \\
5. I am very mentally resilient at work & 3.57 & 0.647 \\
6. I always continue working even when things do not go well & 3.61 & 0.682 \\
\hline DEDICATION & $\mathbf{3 . 7 6}$ & \\
\hline 1. I find the work that I do full of meaning and purpose & 3.76 & 0.703 \\
2. I am enthusiastic about my current job & 3.78 & 0.721 \\
3. The job has inspired me & 3.74 & 0.709 \\
4. I am proud with my current job & 3.71 & 0.644 \\
5. My current job is challenging & 3.71 & 0.717 \\
\hline ABSORPTION & $\mathbf{3 . 7 2}$ & \\
\hline 1. Time flies when I am working & 3.79 & 0.741 \\
\hline
\end{tabular}




$\begin{array}{lll}\text { 2. When I am working, I forget everything else around me } & 3.72 & 0.715 \\ \text { 3. I feel happy when working intensely } & 3.68 & 0.750 \\ \text { 4. I am immersed in my work } & 3.73 & 0.708 \\ \text { 5. I get carried away when I am working } & 3.77 & 0.759 \\ \text { 6. It is difficult to detach me from my current job } & 3.67 & 0.809\end{array}$

\section{Recommendation for Future Research}

The results of the study contribute significantly to the Islamic banker's perspective. It was measured from the point of talent management, succession planning and talent engagement. There is a need for improvement in the talent management system in the banking sector. The Islamic banking sector should develop an entry point banking qualification to avoid wasteful expenses. They need to make sure the talents that they want to hire must form the Islamic banking background. This is to ensure that the talents have already owned the knowledge about the Islamic and conventional banking operation. Indirectly, when the talents have the background of Islamic and conventional banking, they will become more committed to performing their job. It is suggested that more empirical study about this three variables talent management, succession plans and engagement being conducted. The results by using the analysis of cross tabulation, $\mathrm{t}$-test, anova, correlation and regression may enrich the deeper understanding about the phenomena and issues regarding this matter. Other researchers may also add another additional variables such as career development or retention or person job fit in identifying the high performing talents in Islamic banking industry for this kind of research. The Islamic banking should take vital action by sending the talents to the international training program to learn more about Islamic banking sector and at the same time, the talents can adapt the market changes and compete well with other Islamic banks around the world

\section{Conclusion}

The development of Islamic banking and finance industry in previous occasional existences in Malaysia revealed that numerous accomplishments can be seen mostly on the improvement of regulatory transparency, compassionate nationwide demographic facet and product invention of the system in that sector. Allied to these achievements, the Islamic banking and finance should upsurge more highly talented employees to stand in the industry. Islamic banks demand for talents of bankers that are not only well profound with Sharia knowledge but also capable to ascertain the differences between Islamic banking and finance regulation at par with conventional practices.

This study was conducted from the perspectives of the bankers from the Islamic banks in order to have a better understanding of clarifying the factors of talent management, succession planning and talent engagement.Bankers agree that the organization needs an appropriate talent management program to ensure that the current working talents in the Islamic banks are capable in both areas; Islamic and conventional. Most of the banks in the Northern region had been practicing the talent management activities and succession planning program in their organization to ensure that the bankers are engaging well with the banks.With the implementation of succession planning, many bankers can have wellconceived training and development programs to ensure that they have identified and selected the qualified talents that are ready to fill the key positions. The Islamic banking sector should develop an entry point banking qualification to avoid wasteful expenses. To respond to these emerging requirements, the Malaysian Islamic banking sector requires training providers who can develop and deliver a broad range of programs that are in line with professional standards and meet the industry demands.

\section{References}

Alias, A.S., Kamarulzaman, N. R., \&Bhupalan, R. (1994).Islamic Banking in Malaysia: An Overview (1 $1^{\text {st }}$ ed.). Institut Bank-Bank Malaysia (IBBM), Kuala Lumpur. 
Bakker, A. B., Schaufeli, W. B., Leiter, M. P., \&Taris, T. W. (2008). Work engagement: An emerging concept in occupational health psychology. Work and Stress, 22(3), 187-200.

Bakker, A. B., \&Demerouti, E. (2008). The Oldenburg Burnout Inventory: A good alternative to measure burnout and engagement. In J. Halbesleben (Ed.), Stress and burnout in health care. Netherlands: Nova Sciences.

Birdi, K. (2005). No idea? Evaluating the effectiveness of creativity training.Journal of European Industrial Training, 29(2), 102-110.

Brooks, K., \&Nafukho, F. M. (2006). Human resource development, social capital, emotional intelligence: any link to productivity? Journal of European Industrial Training, 30(2), 11-28.

Charan, R., Drotter, S. J., \& Noel, J. L. (2001).The Leadership Pipeline: How to Build the LeadershipPowered Company. San Francisco, California: Jossey-Bass.

Dries, N. (2013). The psychology of talent management: A review and research agenda. Human Resource Management Review 23(4), 272-285.

Garavan, T. N., Carbery, R., \& Rock, A. (2012).Mapping talent development: definition, scope and architecture.European Journal of Training and Development, 36(1), 5-24.

Glen, C. (2007). Fostering talent IT opportunity: Getting past first-base.Strategic Direction, 23(10), 3-5.

Hills, A. (2009).Succession planning - or smart talent management? Industrial and Commercial Training, 41(1), 3-8.

Hughes, J. C., \& Rog, E. (2008). Talent management: A strategy for improving employee recruitment, retention and engagement within hospitality organizations. International Journal of Contemporary Hospitality Management, 20(7), 743-757.

Kaleem, A. (2000). Modelling monetary stability under dual banking system: the case of Malaysia.International Journal of Islamic Financial Services, 2(1), 21-42.

Krejcie, R. V., \&Morgan, D. W. (1970). Determining sample size for research activities.Educational and Psychological Measurement.30(3).607-610.

MIFC (2013).Islamic Finance Talent Development: Global Initiatives. Retrieved May 1, 2017, from http://www.mifc.com.

Morton, L. (2005). Talent management value imperatives: Strategies for execution. Conference Board.

Norasmah, O. (2002). Keberkesanan program keusahawananremaja di sekolahmenengah.PhD thesis, UniversitiPutera Malaysia.

Oxford Advanced Learner's Dictionary (2005). Oxford, England: Oxford University Press.

Pisal, M. (2012).Breaking the barriers: Graduate employment in Islamic finance.Islamic Finance News.

Rollins, C. (2003). Succession planning.Ebscohost, 16(5), 15.

Rothwell, W. J. (2010). Effective succession planning: Ensuring leadership continuity and building talent from within. $\left(4^{\text {th }}\right.$ ed.), New York: American Management Association.

Rowland, M., (2011). How to cement a diversity policy: The key role of talent development.Human Resource Management International Digest, 19(5), 36-38.

Schaufeli, W. B., \& Bakker, A. B. (2003). Utrecht work engagement scale: Preliminary manual. Occupational Health Psychology Unit.Utrecht University, Utrecht.

Towers Perrin. (2009). Employee engagement underpins business transformation. Retrieved May 5, 2017, from

http://www.towersperrin.com/tp/getwebcachedoc?country=gbr\&webc=GBR/2008/200807/TP_IS R_July08.pdf

Xanthopoulou, D., Bakker, A. B., Heuven, E., Demerouti, E., \&Schaufeli, W. R. B. (2009). Work enjoyment and financial returns a diary study on the role of job and personal resources. Journal of Occupational and Organizational Psychology, 82(1), 183-200.

Zigarmi, D., Nimon, K., Houson, D., Witt, D., \& Diehl, J. (2009). Beyond engagement: toward a framework and operational definition for employee work passion. Human Resource Development Review, 8(3), 300-326. 
